\title{
Article \\ Influence of Roof Installation of PV Modules on the Microclimate Conditions of Cattle Breeding Objects
}

\author{
Matúš Bilčík ${ }^{1, * \mathbb{D}}$, Monika Božiková ${ }^{1}$ and Ján Čimo ${ }^{2}$ \\ 1 Department of Physics, Slovak Agricultural University in Nitra, Tr. A. Hlinku 2, 949-76 Nitra, Slovakia; \\ monika.bozikova@uniag.sk \\ 2 Department of Biometeorology and Hydrology, Slovak Agricultural University in Nitra, Tulipánová 7, \\ 949-76 Nitra, Slovakia; jan.cimo@uniag.sk \\ * Correspondence: bilcikmatus@gmail.com; Tel.: +421-37-641-5786
}

Citation: Bilčík, M.; Božiková, M.; Čimo, J. Influence of Roof Installation of PV Modules on the Microclimate Conditions of Cattle Breeding Objects. Appl. Sci. 2021, 11, 2140. https:// doi.org/10.3390/app11052140

Academic Editor: Joachim Müller

Received: 6 February 2021

Accepted: 24 February 2021

Published: 28 February 2021

Publisher's Note: MDPI stays neutral with regard to jurisdictional claims in published maps and institutional affiliations.

Copyright: (c) 2021 by the authors. Licensee MDPI, Basel, Switzerland. This article is an open access article distributed under the terms and conditions of the Creative Commons Attribution (CC BY) license (https:// creativecommons.org/licenses/by/ $4.0 /)$.
Featured Application: The research results are very valuable for practice because they provide a platform for optimizing of internal conditions in cowsheds by monitoring of internal and external breeding parameters. The results also confirm the positive effect of photovoltaic (PV) modules installation on temperature conditions and Temperature-Humidity-Index (THI) values. This fact is important mainly during the seasonal temperature extremes in summer in the Central European region.

Abstract: This paper is focused on the temperature measurements which can detected the influence of temperature changes on the microclimate in animal production building after the installation of photovoltaic (PV) modules. The first series of experiments were performed on a specially designed model cowshed. For the data comparison and verification, the same measurements were realized in real conditions of the animal production object. The temperature balance was identified by measurements of the temperatures in the different parts of roof, PV modules, and the most important were measurements of the ambient temperature and temperatures in three levels of the cowshed interior. For the confirmation of results, measurements were done in two cowsheds, which had the same azimuth orientation and roof slope. The first cowshed was without installation of the PV modules on the roof and the second building had installed PV modules. By the data analyzed from experimentally obtained time-temperature dependencies, it was found that the installation of PV modules on the cowshed roof had a positive influence on the interior temperature balance. The installation of PV also had a positive effect on the cowshed microclimate, which was declared by calculation of the Temperature-Humidity-Index.

Keywords: thermal balance; photovoltaics; Temperature-Humidity—Index

\section{Introduction}

In the last decades, a continuation of the long-term global warming trend was observed, and regional and local impacts have already become apparent [1]. These impacts are expected to become worse with ongoing climate change [2,3]. For Europe, temperature increase is projected in all seasons [4]. Seasonal shifts and changes in frequency and intensity of weather extremes will amplify the impacts in many economic sectors such as agriculture [5]. It is expected that approximately $26 \%$ of all damages and losses associated with medium to large scale climate-related disasters are attributed to agriculture with its sectors crops, livestock, fisheries, aquaculture, and forestry [6]. The situation of optimizing animal husbandry conditions is also addressed by European legislation in the European Convention for the Protection of Animals kept for Farming Purposes, where the obligations to ensure suitable microclimatic conditions of livestock breeding are also formulated.

Increasing air temperature and humidity reduce the ability of cows to cool themselves. Increases in these climate variables lead to, or increase existing, heat stress in cattle [7-10]. Heat 
stress is defined as the sum of external forces acting on an animal that causes an increase in body temperature and evokes a physiological response [11]. Heat stress occurrence can be a phenomenon of one or a few days, but it may also be a phenomenon extending over a certain period. It is the joint result of multiple factors, of which ambient temperature and relative humidity are the two most important ones [12-14]. Other risk factors contributing to heat stress are breed, parity, lactation stage, milk production level, level of feed intake, ration composition, body condition score, feedstuff quality, pasturing condition, housing conditions, and cattle behavior $[15,16]$.

The diagnosis of heat stress can, in general, be set by observing clinical signs in affected cattle and an inventory of risk factors, together with high ambient temperatures and a certain level of relative humidity $[17,18]$. However, sometimes the negative effects of heat stress show up later and indirectly; there is a carry-over effect (summer heat stress can have effects up into autumn).

The parameter of choice to confirm a probability diagnosis based on clinical signs is the Temperature-Humidity-Index, THI [19-21]. It can be calculated with Equation (1).

$$
T H I=0.8 T_{a}+R H\left(T_{a}-14.4\right)+46.4
$$

where $T_{a}$ is the ambient temperature, and $R H$ is the relative air humidity in percentage [22,23].

At a THI $>64$, the heat stress is "mild"; at a THI $>72$, the heat stress is "moderate", and at a THI $>77$, the heat stress is "severe"; at THI > 84, death occurs [24-26].

Cows are well able to adapt to changeable temperature and humidity conditions throughout the year [16]. This can be confirmed by a relatively wide range of neutral temperatures established for dairy cattle. Fluctuations of temperature within a range of $-0.5^{\circ} \mathrm{C}$ to $20.0^{\circ} \mathrm{C}$ and $60-80 \%$ relative humidity [15] is generally accepted as a thermoneutral zone that does not significantly induce physiological or behavioral changes among cows. The level of air temperature generally accepted as $25.0^{\circ} \mathrm{C}-26.0^{\circ} \mathrm{C}$ or $24.0^{\circ} \mathrm{C}-27.0^{\circ} \mathrm{C}[15,27,28]$ is the upper critical temperature, above which the dairy cow welfare is disturbed. Although air temperature and relative humidity may be most important in determining the exchange of heat between the animal and its surroundings, other relevant microclimate factors, such as air movement and sunlight, also play a significant role in levels of heat stress [29-31]. Changes in air velocity influence the convection cooling of cattle which, in combination with solar radiation, has a very significant impact on the regulation of the thermal balance of cows $[32,33]$. Legislative support for the optimization of living conditions of animal husbandry is expressed in the European Convention for the Protection of Animals kept for Farming Purposes where the obligations to ensure suitable microclimatic conditions of livestock breeding are also formulated.

Agriculture also faces the problem of increasing dependency on energy sources. Electrical energy is needed for lighting, water pumping, air-conditioning of cowsheds, greenhouses, warehouses, administration buildings, etc. In the farms are large buildings with flat roofs, which offer ideal conditions for the photovoltaic system installation. Agrivoltaics are popular nowadays, and is described in the literature [34-38]. Research was performed based on presented facts, focused on photovoltaic (PV) modules installation to the microclimate of selected agricultural buildings. In particular, thermal conditions were examined by experiments on the model cowshed and also on the two real cowsheds. The main aim of this research was the identification of temperature changes after the photovoltaic modules installation on the cowshed roof. The next aim was the calculation of Temperature-Humidity-Index and the quantitative and qualitative evaluation of microclimate changes in the cowshed. The results of the research should support the willingness of farmers to install PV modules on cowshed roofs in the climatic conditions of Central Europe. Research results should refute the claims about the overheating of the cowshed interior after the installation of PV modules.

\section{Materials and Methods}

For measurements of microclimate changes in the interior space of the building after photovoltaic module installation was designed the model cowshed. The model cowshed 
is showed on (Figure 1a) and its dimensions were $a=570 \mathrm{~mm}, b=600 \mathrm{~mm}, c=830 \mathrm{~mm}$, $\mathrm{d}=700 \mathrm{~mm}$, and the angle of the roof inclination was $\alpha=43.5^{\circ}$. The model roof was covered with the same roofing material made of aluminum as a real object; the thickness of the aluminum sheet was $1 \mathrm{~mm}$. The side walls of the model building were made of MDF boards. In terms of thermophysical properties, a material (MDF board) was chosen for the model object due to similar thermal properties as the thermal insulation tarpaulin used as a covering of the side walls of the cowshed in real conditions. The thermal conductivity of the MDF board used for model building was $0.073 \mathrm{~W} \cdot \mathrm{m}^{-1} \cdot \mathrm{K}^{-1}$. The thickness of MDF board was $25 \mathrm{~mm}$, and the thermal resistance of $0.342 \mathrm{~m}^{2} \cdot \mathrm{K} \cdot \mathrm{W}^{-1}$. Thermal conductivity was measured in Thermophysical laboratory (Department of Physics, SUA in Nitra, Nitra Slovakia) by instrument Isomet 2104 (Applied Pecision Ltd., Bratislava, Slovakia). The thermal insulation tarpaulin used as a wall in a real cowshed has a thermal resistance $0.340 \mathrm{~m}^{2} \cdot \mathrm{K} \cdot \mathrm{W}^{-1}$. Diffusion resistance of the used material was the same.

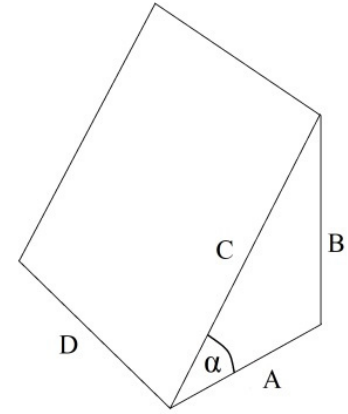

a

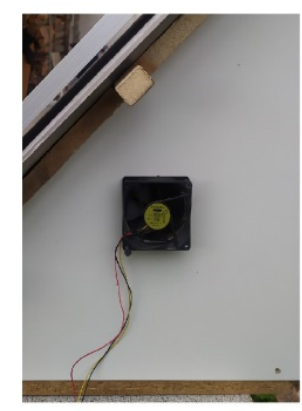

b

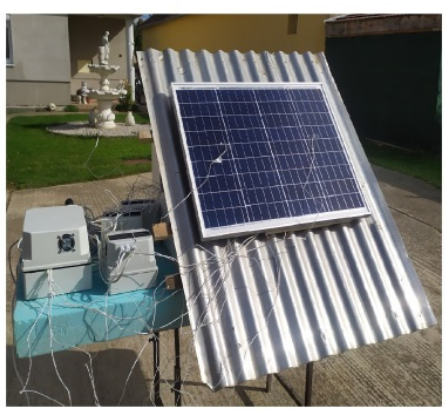

$\mathrm{c}$

Figure 1. (a) The model dimensions designation; (b) detail of model building with fan integrated on the facade; (c) the experimental equipment with photovoltaic (PV) module on the roof.

The realization of the model building took into account the fact that in the conditions of Central Europe, the natural ventilation of the building is used for at least 10 months a year in combination with ventilation equipment. It was the main reason for the installation of two computer fans with diameters of $80 \mathrm{~mm}$ that were used to simulate the cooling and air flow in the model building (Figure 1b). The fans were used to simulate the air flow that occurs in the cowshed. The main function of fans was blowing air out of the model. The fans work all the time, but the power of the fans was regulated continuously by potentiometer so that the speed of the air flow in the interior proportionally corresponded to the real conditions in a specific season. Air velocity in the model building and the real cowshed was measured throughout the whole experimental period by using dataloggers Comet S-3121 (COMET SYSTEM Ltd., Rožnov pod Radhoštěm, Czech Republic) and instrument Testovent 06995100 (Testo SE \& Co., Titisee-Neustadt, Germany). The ventilation system was used in full, especially in the summer months from June to August. Both external and internal conditions were taken into account in the experimental simulation. The average air flow velocity in a real cowshed in the summer period was in range $(0.7-1.2) \mathrm{m} \cdot \mathrm{s}^{-1}$, in the winter period the air flow velocity was from 0.2 to $0.25 \mathrm{~m} \cdot \mathrm{s}^{-1}$. During the spring season, the average value of the air flow velocity was $0.45 \mathrm{~m} \cdot \mathrm{s}^{-1}$, and in the autumn $0.56 \mathrm{~m} \cdot \mathrm{s}^{-1}$. In calculating the air flow rate, we used the information presented by Holmes et al. (2013), which states as an optimum 40 to 60 air changes per hour. During the measurements in the model building, fifty times air changes per hour were ensured. It means the volume flow, approximately $6 \mathrm{~m}^{3} \cdot \mathrm{h}^{-1}$, corresponds to the average velocity of air $0.04 \mathrm{~m} \cdot \mathrm{s}^{-1}$ in the model building. Herkner et al. (2002) claim that the required air flow depends on the temperature, and for the temperature range $(10-28){ }^{\circ} \mathrm{C}$, they correspond to the air flow rates in the cowshed $(0.1-1.3) \mathrm{m} \cdot \mathrm{s}^{-1}$. The exterior air flow velocities were also taken into account for calculation.

One of the most important microclimate parameters is the temperature. Temperatures were measured with a specially designed and constructed measuring device, which is 
described in the next part. The measurements were performed in two ways. At first, temperatures in the different parts of model object were detected without installation of the photovoltaic module on the model roof. The second experiment was focused on the temperature measurements after installation of the photovoltaic module on the model roof (Figure 1c).

For measurements, we used two different types of PV modules. Monocrystalline PV module [39] type SZ-50-36M (Solarfarm, Utrecht, The Netherlands) and polycrystalline PV module [40] type SPP50-10/3a (Victron energy, Almere, The Netherlands).

Temperature measurements were performed by temperature sensors REED TP-01 (REED Instruments, Newmarket, ON, Canada) with the accuracy of measurement $\pm 0.75 \%$ [41]. A measuring device was set up to measure the temperature 24 times per hour. Temperature sensors were placed with transparent tape from the upside of the roofing, and also from the downside of the roofing and photovoltaic module. One temperature sensor was located between the photovoltaic module and roof sheet. The next one was placed near the roof of the model cowshed. The function of mentioned sensor was detection of the ambient temperature.

Measurements were carried out in the interior of the model cowshed by 12 temperature sensors. The temperature sensors were arranged in three levels: The 1st level-up (S1), middle-the 2nd level (S2 and S3), and the 3rd level-down (S4). The levels are illustrated in Figure 2a with red dots. Real positions of sensors are shown on Figure 2b. The sensor distances are given in Table 1. Temperature sensors in the group were spaced $150 \mathrm{~mm}$ apart. The layout of the temperature sensors allowed measuring the temperature across the whole model cowshed. The data processing was applied on the measurement results obtained for every season during the year, but detailed results are presented for three model days with similar weather conditions. The model day was extracted from the data obtained for every season (e.g., autumn) by comparison of experimentally obtained day data, and then the average values were calculated for every time point. A correlation analysis was applied on the experimental data. The model day was selected for the best correlation between the data measured during the whole evaluation period and average values for the same period. For every evaluated day the obtained parameters (ambient temperature, relative air humidity, wind speed, intensity of solar radiation) were compared with the monthly average for each point of graphical dependencies. The model day of the season had a high degree of correlation with the average monthly parameters.

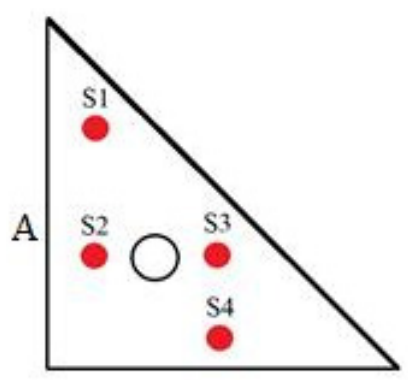

a

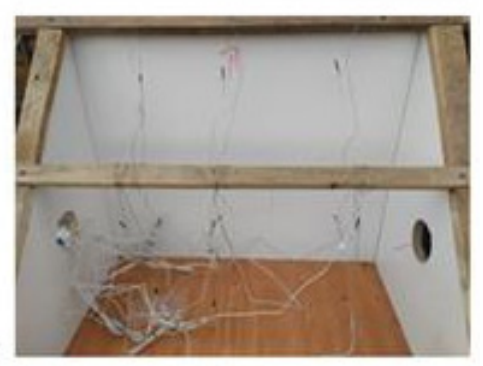

b

Figure 2. (a) Layout of temperature sensors; (b) installed temperature sensors inside the model cowshed.

In particular, the ambient temperature was approximately the same during the day. Measured data for data analysis were selected in the time range from 12 p.m. to 3 p.m. The mentioned time was chosen because the maximum intensity of solar radiation is reached in this period. The next reason for the selection of the mentioned time range was the fact that the PV system produces the maximum energy, and the last reason was the greatest thermal stress of animals in this time interval, which has a direct influence on the THI (THI reaches the maximum). The experiments were performed continuously during the day and night, but no measurable effect on the interior conditions after the PV modules installation 
at night was found. From the solar radiation intensity point of view, the PV modules installation on the cowshed roof was not considered as significant for night conditions. Monitoring of cow behavior was not performed.

Table 1. Temperature sensor distances.

\begin{tabular}{ccc}
\hline Group of the Sensors & $\begin{array}{c}\text { Distance from the Roof } \\
(\mathbf{m m})\end{array}$ & $\begin{array}{c}\text { Distance from the Wall A } \\
(\mathbf{m m})\end{array}$ \\
\hline S1 & 80 & 30 \\
S2 & 400 & 30 \\
S3 & 80 & 330 \\
S4 & 400 & 330 \\
\hline
\end{tabular}

\section{Results}

The results are divided into five parts, according to the experimental set up.

3.1. Measurements of the Temperature in the Model Cowshed Interior and Exterior without Installed Photovoltaic Module on the Roof

The example of measurement results for the 1st selected model day in October. The simulation was performed without a photovoltaic module on the model roof. Average ambient temperature in the mentioned time range was $24.2^{\circ} \mathrm{C}$. The upside part of the aluminum roof sheet had an average temperature of $30.4{ }^{\circ} \mathrm{C}$, and downside part, $32.4{ }^{\circ} \mathrm{C}$ (Figure 3).

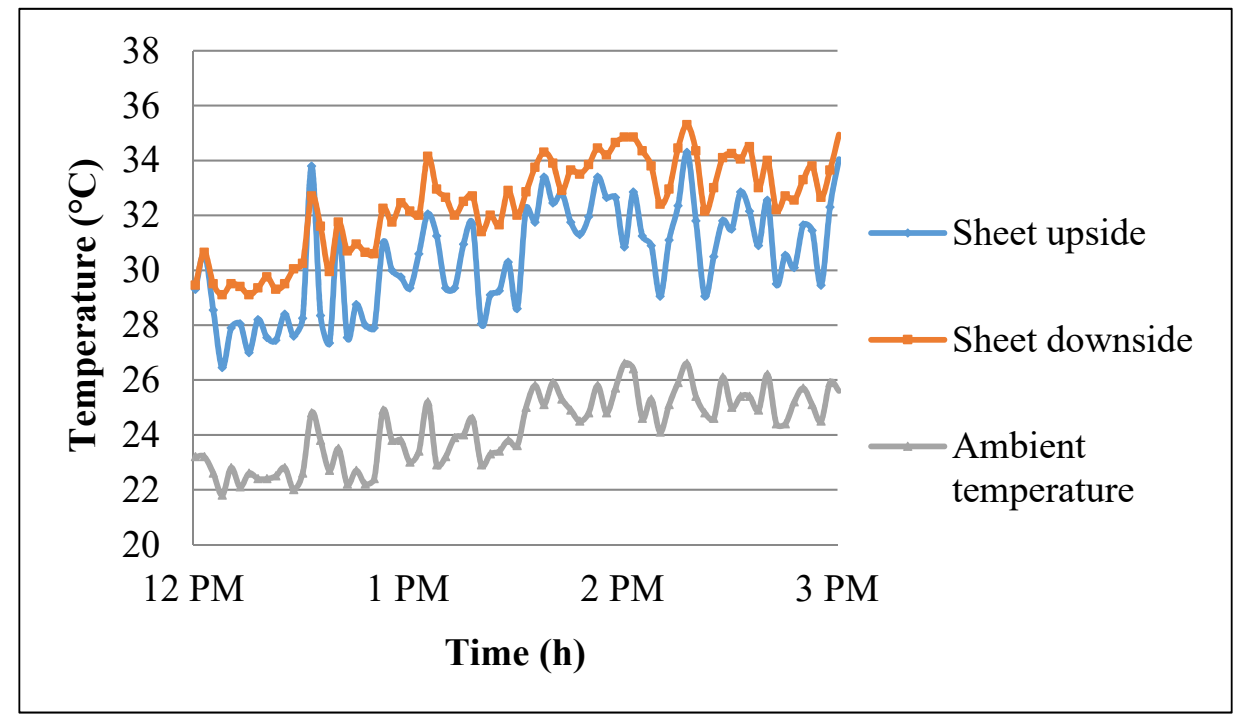

Figure 3. Time dependencies of roof sheet temperature and ambient temperature for model cowshed without installation of PV module.

The time-temperature dependencies for different parts of model cowshed without PV modules are presented on Figure 4. From the presented results, it is evident that the upper part of the model cowshed was the coldest with an average temperature of $21.5^{\circ} \mathrm{C}$. The middle part of the object had an average temperature of $26.5^{\circ} \mathrm{C}$, and down part of the model cowshed had an average temperature of $23.6^{\circ} \mathrm{C}$. 


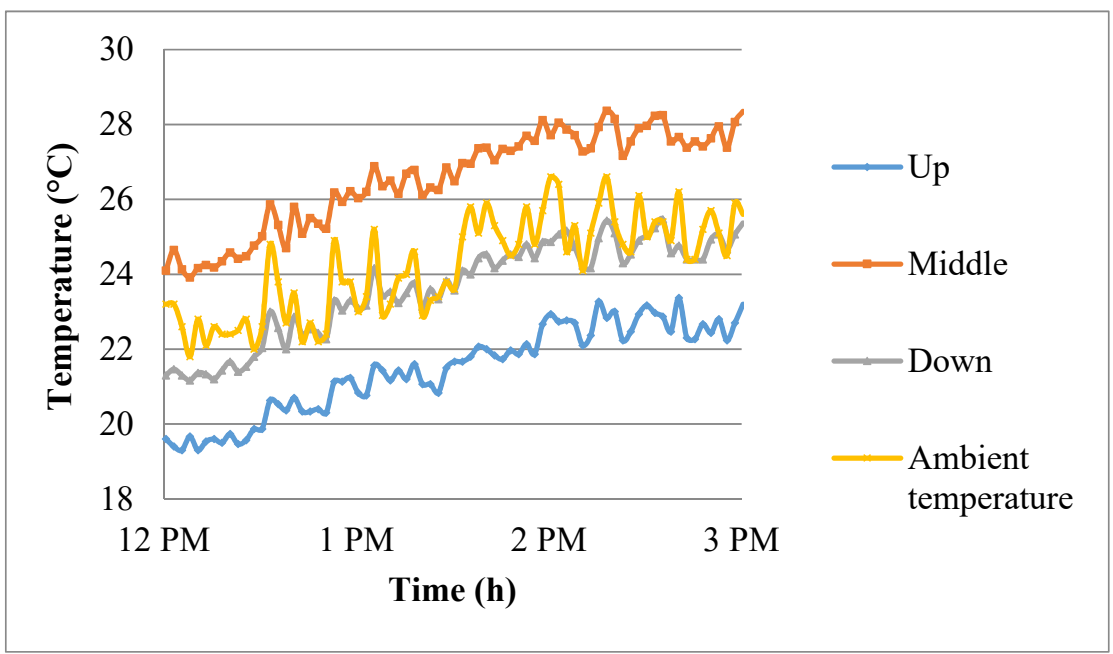

Figure 4. Time-temperature dependencies measured in different distances from the roof of model cowshed without installation of PV module and the ambient temperature.

3.2. Measurements of the Temperature in the Model Cowshed Interior and Exterior with Installed Polycrystalline Photovoltaic Module on the Roof

In the frame of this measurement, the polycrystalline photovoltaic module SPP5010/3a was installed on the model cowshed roof. Because aluminum roofing has corrugation, the distance between the roofing and photovoltaic module was $20 \mathrm{~mm}$ (minimum) and $40 \mathrm{~mm}$ (maximum). The temperature sensor was installed in a distance of $20 \mathrm{~mm}$ from the roof.

The results obtained from the 2nd selected model day in October were evaluated and processed. Time temperature dependence (Figure 5) showed the course for sheet upside, downside, and ambient temperature. Ambient temperature and temperature of aluminum roof sheet downside was very similar, on average $\pm 24.5^{\circ} \mathrm{C}$. The average temperature $26.8^{\circ} \mathrm{C}$ was experimentally detected on the upside roof sheet surface.

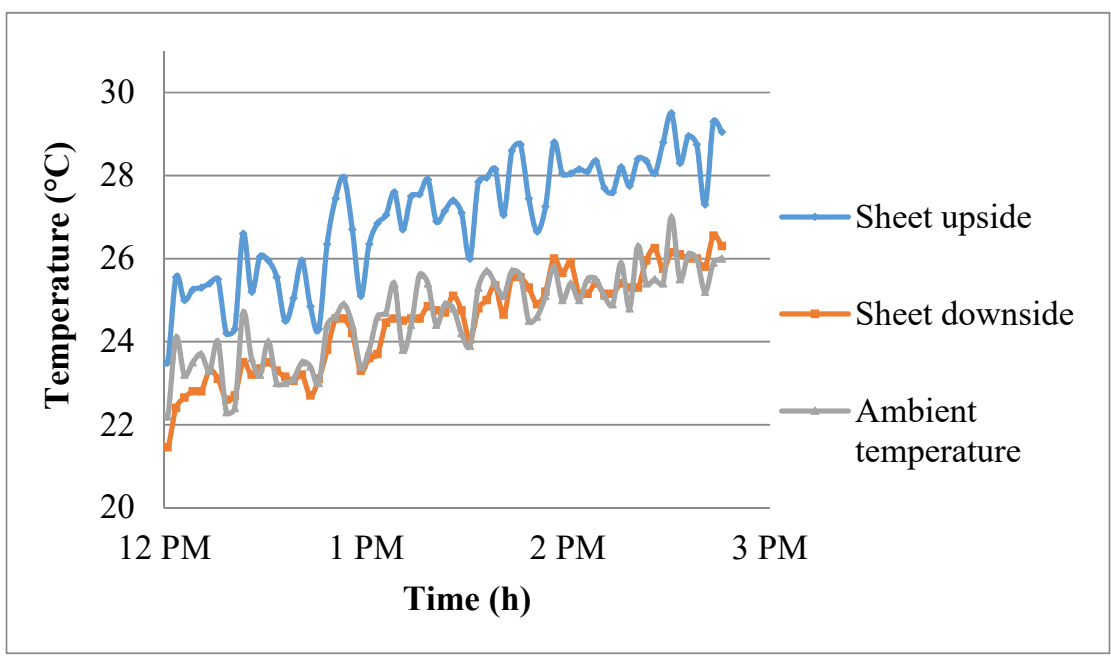

Figure 5. Time dependencies of roof sheet temperature and ambient temperature for model cowshed with installation of polycrystalline PV module.

The graphical relations on Figure 6 present experimentally obtained time-temperature dependencies. From the dependencies, it is obvious that the smallest difference was identified between the temperature in the middle part of the model cowshed and the ambient temperature, and the average difference was $0.9^{\circ} \mathrm{C}$. The upper part of the model 
cowshed was the coldest, with an average temperature of $20.9^{\circ} \mathrm{C}$. The down part had an average temperature of $22.6^{\circ} \mathrm{C}$.

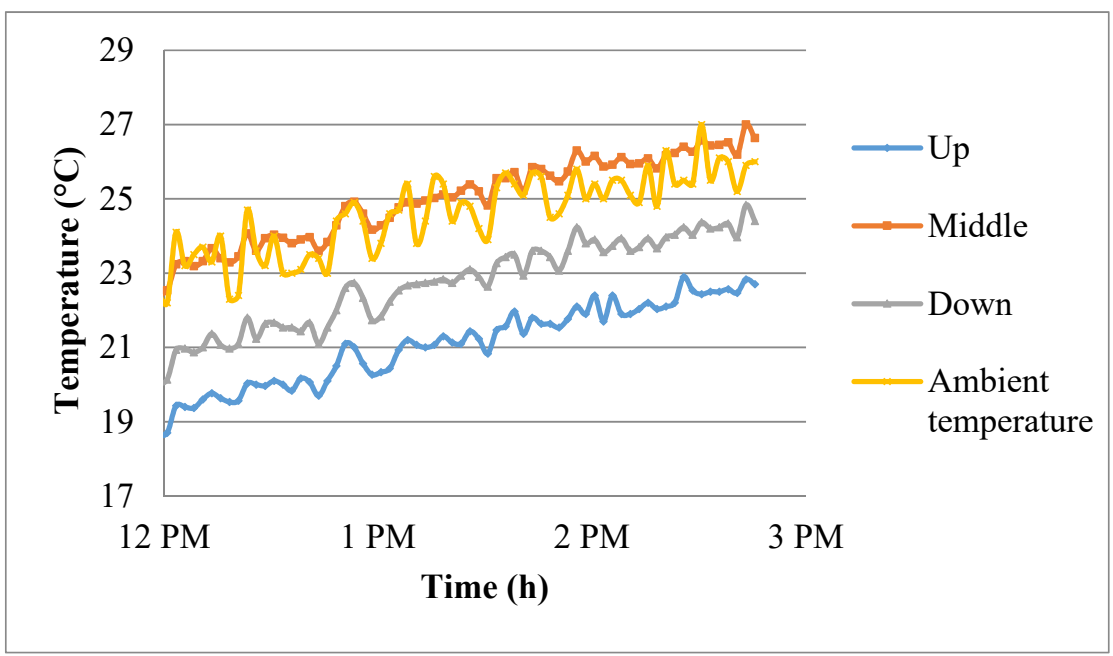

Figure 6. Time-temperature dependencies measured in different distances from the roof of model cowshed with installation of polycrystalline PV module and the ambient temperature.

Trend of the temperature changes between the aluminum roof sheet and polycrystalline photovoltaic module is presented on the Figure 7. The temperature between roof and photovoltaic module was on average $27.2^{\circ} \mathrm{C}, 2.6^{\circ} \mathrm{C}$ above the ambient temperature. The average temperature of the polycrystalline photovoltaic module upside was $36.7^{\circ} \mathrm{C}$. The downside part of the photovoltaic module was hotter, with an average temperature of $41.9^{\circ} \mathrm{C}$.

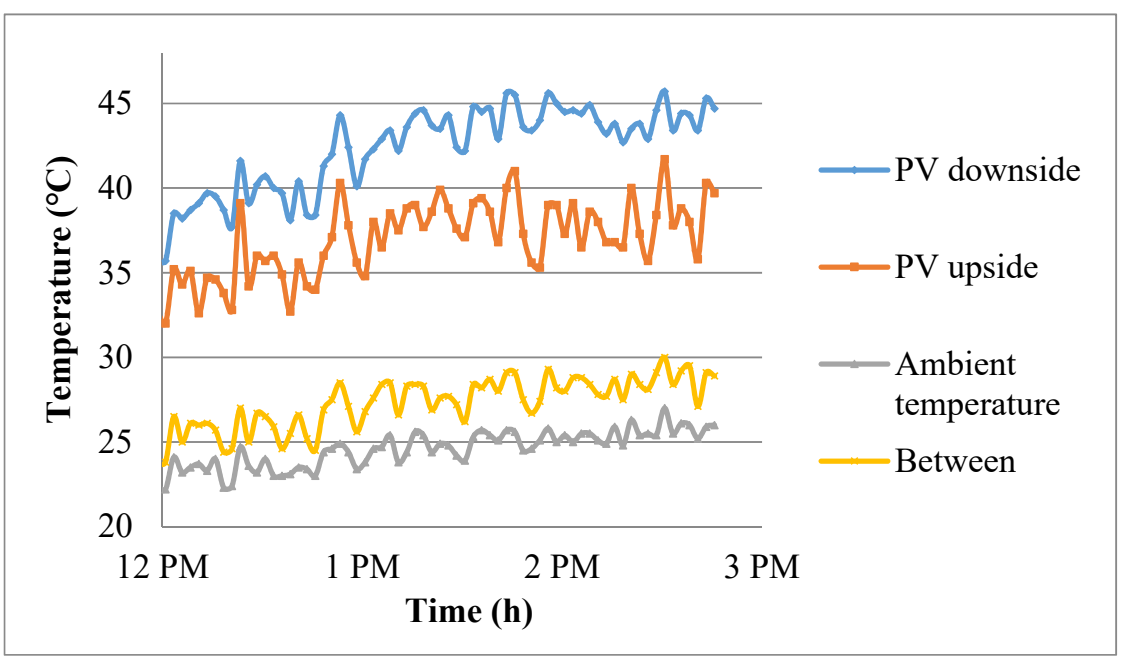

Figure 7. Time dependencies of polycrystalline photovoltaic module parts temperature, ambient temperature, and temperature between photovoltaic module and roof sheet.

3.3. Measurements of the Temperature in the Model Cowshed Exterior and Interior with Installed Monocrystalline Photovoltaic Module on the Roof

The experimental set up was the same as in the previous experiments, but the monocrystalline photovoltaic module SZ-50-36M was installed on the roof of model cowshed. The same time-temperature relations were measured, analyzed, and evaluated for the 3rd selected model day in October. The measured data for two different parts of the roof sheet and the ambient temperature are shown in Figure 8. From the presented dependencies, it is obvious that the roof sheet's downside part had almost the same temperature 
as the ambient temperature. On average, it is $\pm 25.1^{\circ} \mathrm{C}$. The aluminum roof sheet upside part had a higher average temperature of $28.3^{\circ} \mathrm{C}$.

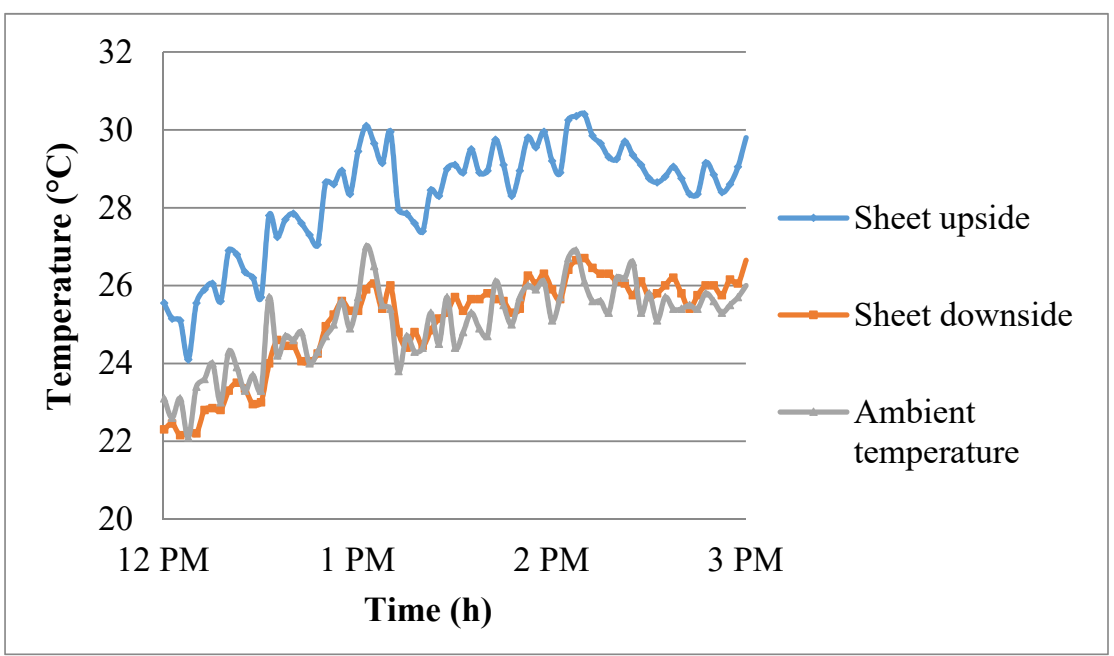

Figure 8. Time dependence of roof sheet temperature and ambient temperature for model cowshed with installation of monocrystalline PV module.

As in the previous case, the trend of graphical relations for ambient temperature and the temperature of model cowshed middle part was similar. From measured data, it was calculated that the average ambient temperature was $25.1^{\circ} \mathrm{C}$, and the average value of the temperature in the middle part of the model object was $25.4^{\circ} \mathrm{C}$. From the temperature point of view, the coldest was the upper part of the model cowshed, with an average temperature of $21.4^{\circ} \mathrm{C}$, and for the down part of the model cowshed, the average temperature was $23.1^{\circ} \mathrm{C}$ (see Figure 9).

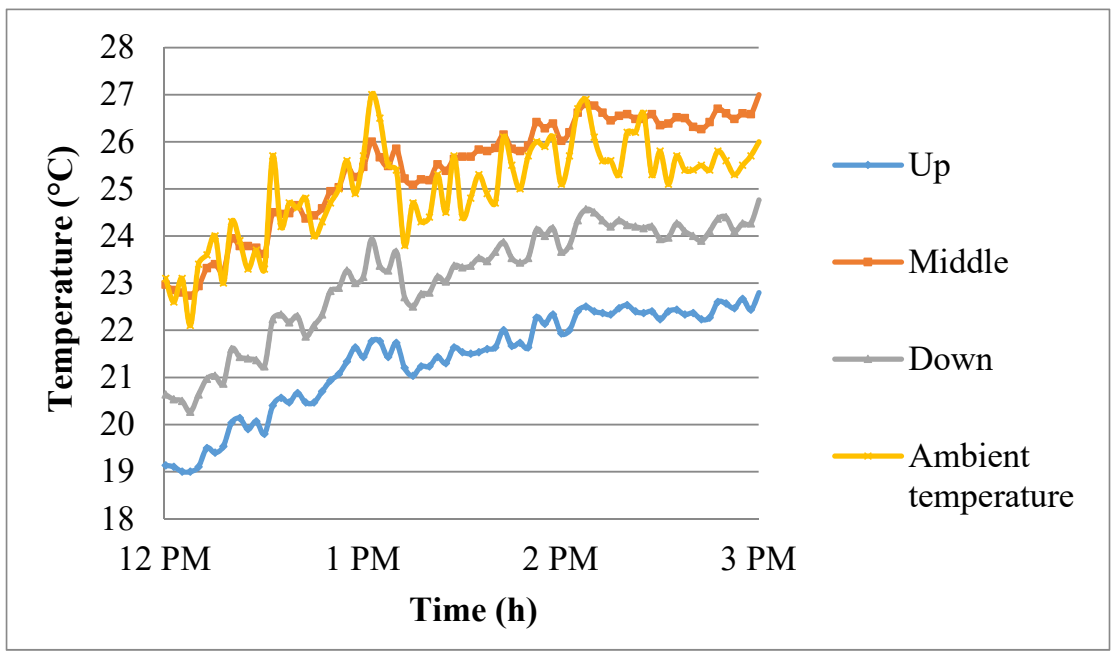

Figure 9. Time-temperature dependencies measured in different distances from the roof of the model cowshed with installation of monocrystalline PV module and the ambient temperature.

Average temperature identified between the roof sheet and the monocrystalline photovoltaic module was $28.8^{\circ} \mathrm{C}$, which is $3.7^{\circ} \mathrm{C}$ above the ambient temperature. The upside part of the photovoltaic module had an average temperature of $30.1^{\circ} \mathrm{C}$. The average temperature calculated for the downside part of the PV module was $46.1^{\circ} \mathrm{C}$ (Figure 10). 


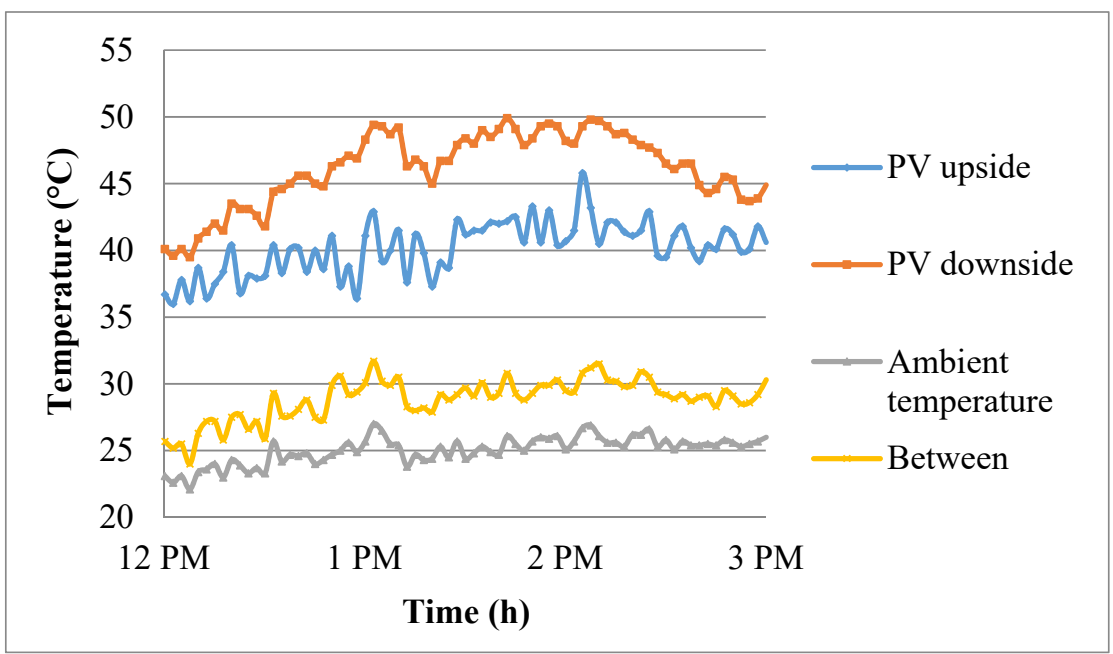

Figure 10. Time dependencies of monocrystalline photovoltaic module parts temperatures, ambient temperature, and temperature between the PV module and roof sheet.

3.4. Measurements of the Temperature in the Real Cowshed with and without Installed Photovoltaic Module on the Roof

For validation of the obtained results, the same experiments were repeated in the real conditions. The measurements were performed in the cowshed, which is located in the farm situated in the southern region of Slovakia. There were measured temperatures on the two different animal production objects, which had the same azimuth orientation and the roof slope. The first building was without installation of the PV modules on the roof, and the second building had installed the PV modules on the roof. For data comparison, we selected days with similar weather conditions as in the previous experiments. Measurements were done in two model days in October. First, we performed measurements in the building without installation of the PV modules, and then we repeated the same experiments in the building with installed PV modules. The layout of the sensors was the same as in the model cowshed. The data identified by the measurements were numerically processed and then the average values of the temperatures were calculated, as presented in Table 2. Ambient temperatures during measurements were very similar in average $23.6^{\circ} \mathrm{C}$ and $23.7{ }^{\circ} \mathrm{C}$.

Table 2. Average temperatures calculated from measured data in real operating conditions of the cowshed.

\begin{tabular}{|c|c|c|c|}
\hline Cowshed Roof & $\begin{array}{c}\text { Ambient } \\
\text { Temperature } \\
\left({ }^{\circ} \mathrm{C}\right)\end{array}$ & $\begin{array}{c}\text { Roof Sheet } \\
\text { Downside } \\
\text { Temperature } \\
\left({ }^{\circ} \mathrm{C}\right)\end{array}$ & $\begin{array}{c}\text { Inside-Under Roof } \\
\text { Temperature } \\
\left({ }^{\circ} \mathrm{C}\right)\end{array}$ \\
\hline Without PV & 23.6 & 31.0 & 21.8 \\
\hline Polycrystalline PV & 23.7 & 25.1 & 20.4 \\
\hline Cowshed Roof & $\begin{array}{c}\text { Inside-Middle Part } \\
\text { Temperature } \\
\left({ }^{\circ} \mathrm{C}\right)\end{array}$ & $\begin{array}{c}\text { Inside-Down Part } \\
\text { Temperature } \\
\left({ }^{\circ} \mathrm{C}\right)\end{array}$ & $\begin{array}{c}\text { Inside-Average } \\
\text { Temperature } \\
\left({ }^{\circ} \mathrm{C}\right)\end{array}$ \\
\hline Without PV & 24.4 & 23.1 & 23.1 \\
\hline Polycrystalline PV & 23.7 & 21.6 & 21.9 \\
\hline
\end{tabular}

Graphical results of the temperature measurements in cowshed without photovoltaic modules on the roof are shown in Figure 11. From the trend of dependency, it is clear that temperature inside was the lowest. The average difference between the ambient temperature and the inside temperature value was about $0.5^{\circ} \mathrm{C}$. The roof sheets downside part had an average temperature of $31^{\circ} \mathrm{C}$. 


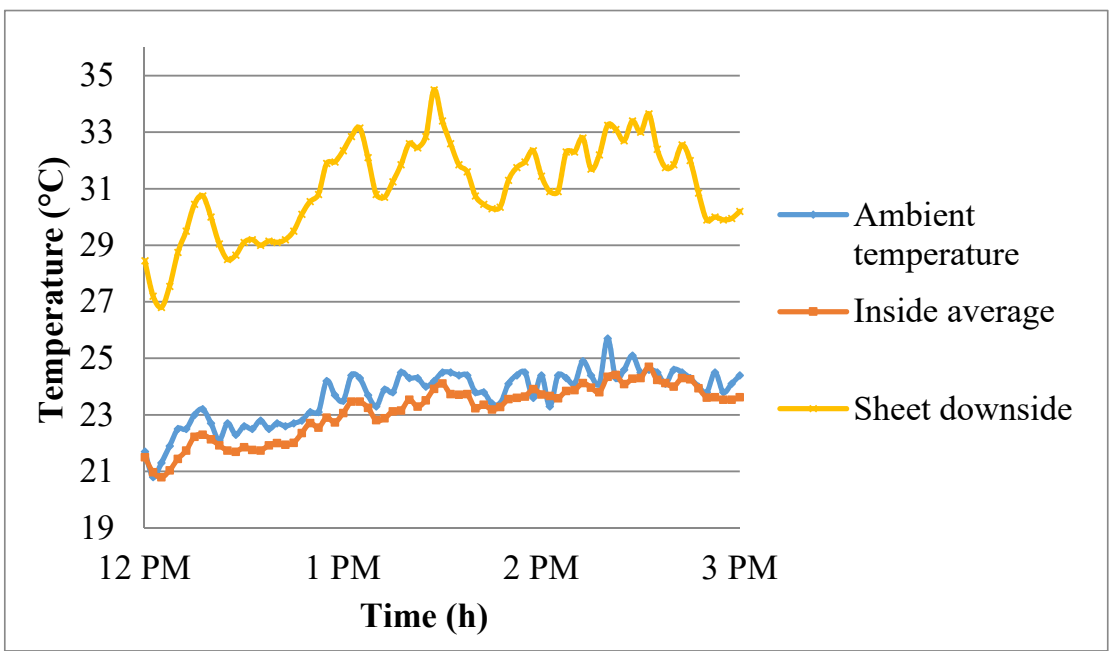

Figure 11. Time dependence of roof sheet temperature and ambient temperature for real cowshed without installation of photovoltaic modules on the roof.

The time-temperature dependencies in case of the roof with installed photovoltaic modules are presented as a graphical relation in Figure 12. The experimentally detected data were processed and compared. The obtained results show that the difference between temperature inside and ambient temperate is approximately $1.8^{\circ} \mathrm{C}$. This difference is bigger than in the previous case.

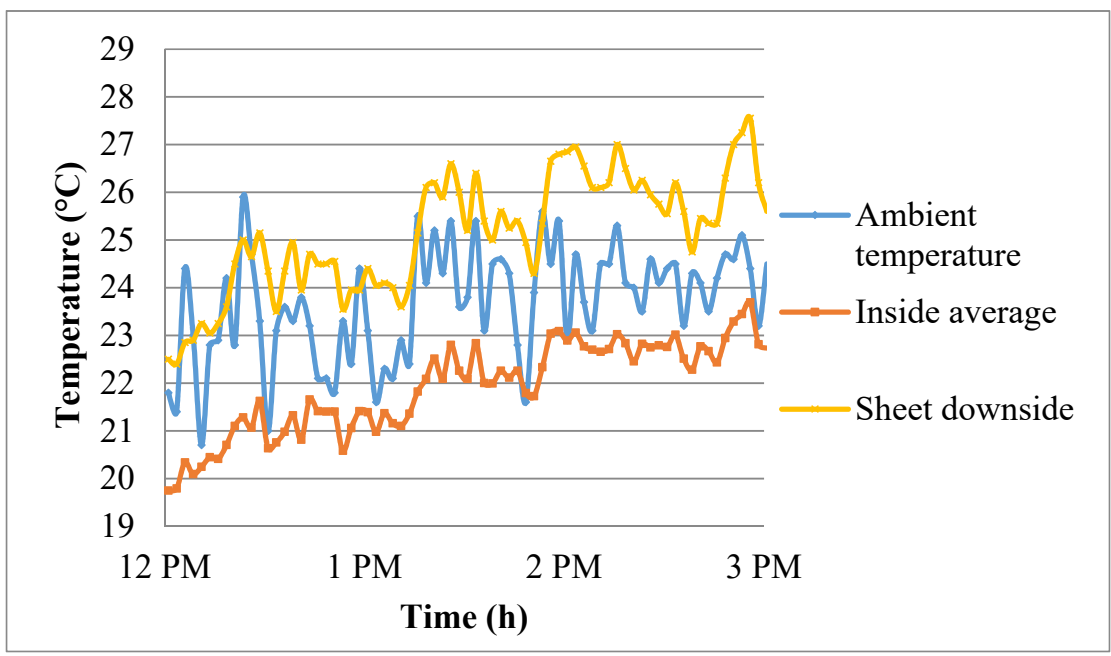

Figure 12. Time dependence of roof sheet temperature and ambient temperature for real cowshed with installation of photovoltaic modules on the roof.

In general, experimentally obtained results under real conditions confirmed the fact that the inside temperature is higher under the roof without installed photovoltaic modules in the model cowshed.

For the results comparison, a correlation analysis was performed. A correlation was detected between temperatures obtained from the model cowshed and real cowshed. There was a significant correlation for the inside temperatures, with a correlation coefficient of 0.9 .

The same experiments were also performed during the winter and summer season, and the results confirmed the fact that installation of PV modules on the cowshed roof in real conditions has a positive influence on the interior temperature and also on the internal microclimatic conditions. During the summer, a decreasing of the interior temperature under the cowshed roof after the PV modules installation was detected, but the opposite 
temperature effect was observed during the winter, after the installation of PV modules. The temperature in the interior of the cowshed increased. The influence of the PV modules installation on the cowshed macroclimate is discussed in detail in the next part.

\subsection{The Summary of Experimental Results for Different Seasons}

In order to confirm the validity of the results, Table 3 shows the summary of the average values for exterior conditions (ambient temperature, solar radiation intensity, relative air humidity, and wind velocity) and interior conditions (interior temperature, relative air humidity, and average air velocity). The interior temperatures are presented as ranges. The maximum temperatures $(22-26){ }^{\circ} \mathrm{C}$ were detected for summer, but the hottest days have temperatures during the evaluated time period about $32{ }^{\circ} \mathrm{C}$. The temperature minimum (0-12) ${ }^{\circ} \mathrm{C}$ was obtained for the winter season. Since the temperature values in the exterior and interior are directly related to the intensity of solar radiation, a correlation analysis was performed. The correlation between indoor and outdoor temperature is expressed by a correlation coefficient of 0.928 and the correlation between the intensity of solar radiation and indoor temperature by a coefficient of 0.958 during the model day in autumn (Figure 13). The graphical relations for solar radiation intensity in sunny, cloudy, and model day are presented in the Figure 14.

Table 3. The summary of external and internal conditions in context of Temperature-HumidityIndex (THI).

\begin{tabular}{|c|c|c|c|c|}
\hline \multicolumn{5}{|c|}{ Exterior Conditions } \\
\hline Average Values & Spring & Summer & Autumn & Winter \\
\hline $\begin{array}{c}\text { Ambient } \\
\text { temperature }\left({ }^{\circ} \mathrm{C}\right)\end{array}$ & 8.8 & 23.9 & 12.2 & 1.4 \\
\hline $\begin{array}{l}\text { Solar radiation } \\
\text { intensity } \\
\left(\mathrm{kWh} \cdot \mathrm{m}^{-2}\right)\end{array}$ & 2.15 & 3.15 & 1.26 & 0.71 \\
\hline $\begin{array}{c}\text { Relative } \\
\text { humidity (\%) }\end{array}$ & 66.7 & 64.0 & 76.3 & 78.7 \\
\hline $\begin{array}{l}\text { Wind velocity } \\
\left(\mathrm{m} \cdot \mathrm{s}^{-1}\right)\end{array}$ & 1.4 & 1.0 & 0.9 & 1.2 \\
\hline \multicolumn{5}{|c|}{ Interior Conditions } \\
\hline Average Values & Spring & Summer & Autumn & Winter \\
\hline $\begin{array}{c}\text { Interior } \\
\text { temperature }\left({ }^{\circ} \mathrm{C}\right)\end{array}$ & 12-19 & $22-26$ & $11-18$ & $0-12$ \\
\hline $\begin{array}{c}\text { Relative } \\
\text { humidity (\%) }\end{array}$ & $46-63$ & $35-55$ & $40-65$ & $45-78$ \\
\hline $\begin{array}{c}\text { Average air } \\
\text { velocity }\left(\mathrm{m} \cdot \mathrm{s}^{-1}\right)\end{array}$ & 0.22 & 0.90 & 0.22 & 0.22 \\
\hline $\begin{array}{c}\text { Average THI } \\
\text { without PV } \\
\text { system (-) }\end{array}$ & 59.35 & 69.90 & 58.03 & 45.97 \\
\hline $\begin{array}{c}\text { Average THI } \\
\text { with PV system } \\
(-)\end{array}$ & 58.31 & 66.90 & 57.05 & 46.48 \\
\hline
\end{tabular}

Overview of the solar radiation intensity values for different seasons is presented in Table 3. There is evidence that solar radiation intensity varies from $0.71 \mathrm{kWh} \cdot \mathrm{m}^{-2}$ in the winter season to $3.15 \mathrm{kWh} \cdot \mathrm{m}^{-2}$ during the summer. From summary results, it is clear that the intensity of solar radiation has a direct influence on the exterior temperature. The values of the wind velocity values change depending on the season from $1.4 \mathrm{~m} \cdot \mathrm{s}^{-1}$ in spring to $0.9 \mathrm{~m} \cdot \mathrm{s}^{-1}$ in autumn. There was no detected correlation between the exterior wind velocity and average air velocity in the interior due to the usage of the ventilation system in the interior. The air velocity in the real cowshed was on average $0.2 \mathrm{~m} \cdot \mathrm{s}^{-1} \mathrm{during}$ 
the spring, autumn, and winter, but in summer the air velocity reached a maximum value $0.9 \mathrm{~m} \cdot \mathrm{s}^{-1}$ due to the increased demand for the interior cooling.

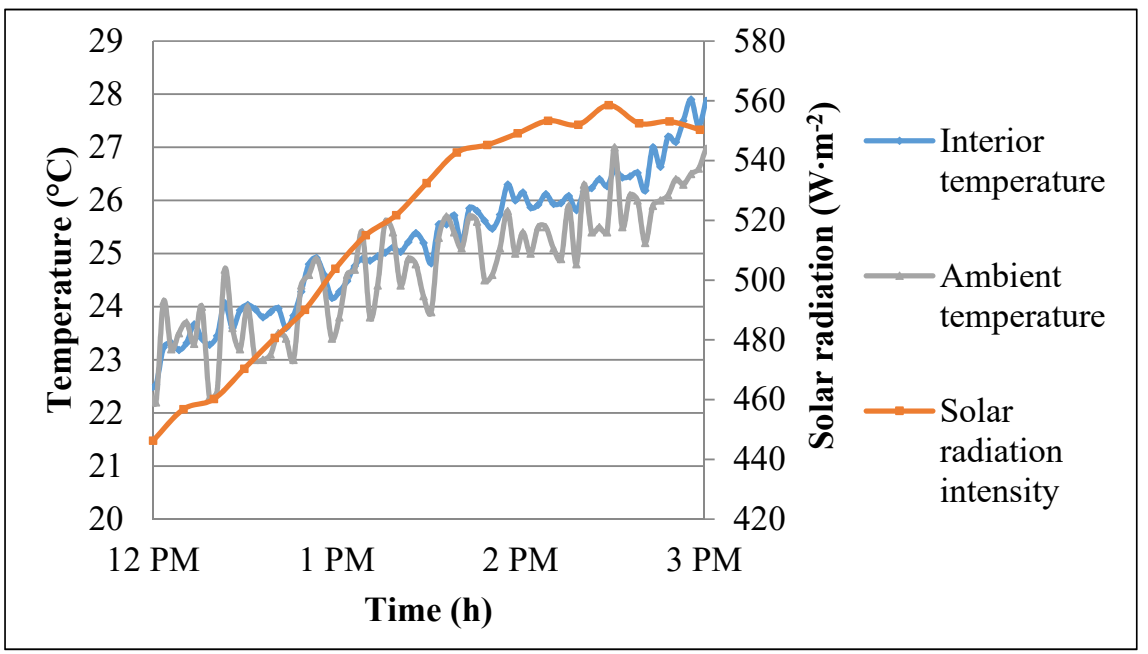

Figure 13. The relations for solar radiation intensity, ambient temperature, and interior temperature during the evaluated time period.

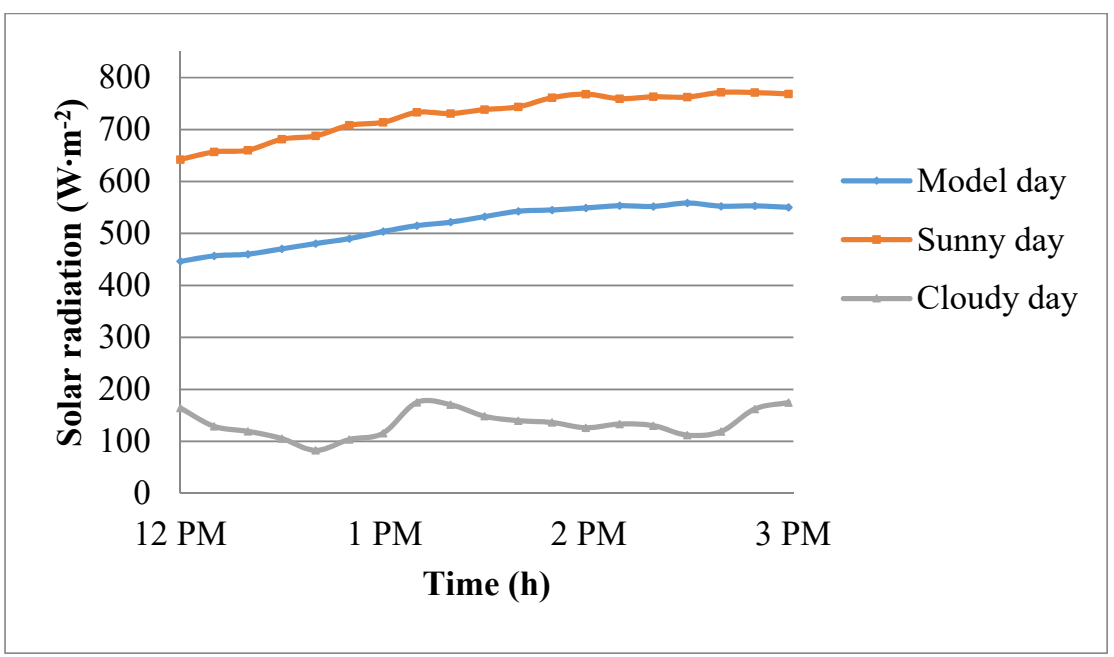

Figure 14. The relations for solar radiation intensity during the sunny, cloudy, and model day.

Relative humidity was measured in the exterior and interior. The exterior humidity varies from $64.0 \%$ to $78.7 \%$. The highest difference between the exterior and interior relative humidity was $19 \%$. Figure 15 displays relations for ambient temperature and relative humidity during the year. There was no confirmed correlation between mentioned parameters because of a very small correlation coefficient, -0.618 . The interesting results were identified during the model day in October presented in Figure 16. The correlation coefficient for relations between the exterior and interior relative humidity dependencies was near 1 . The connection between exterior and interior humidity during the spring and autumn is also evident from values in Table 3. 


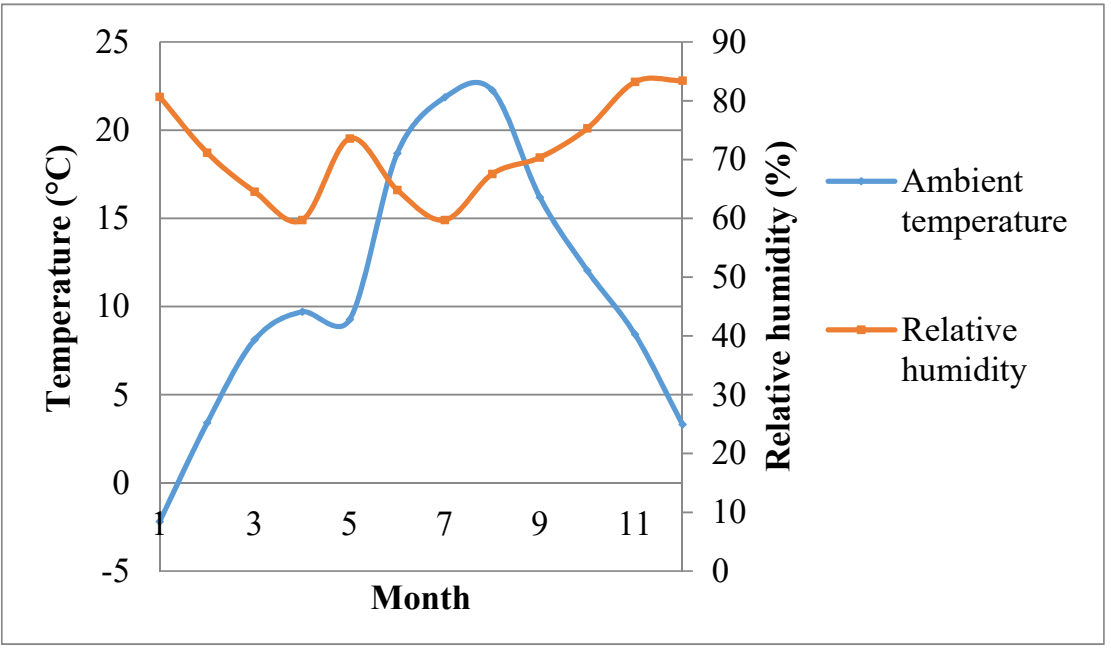

Figure 15. The relations for ambient temperature and relative humidity during the year.

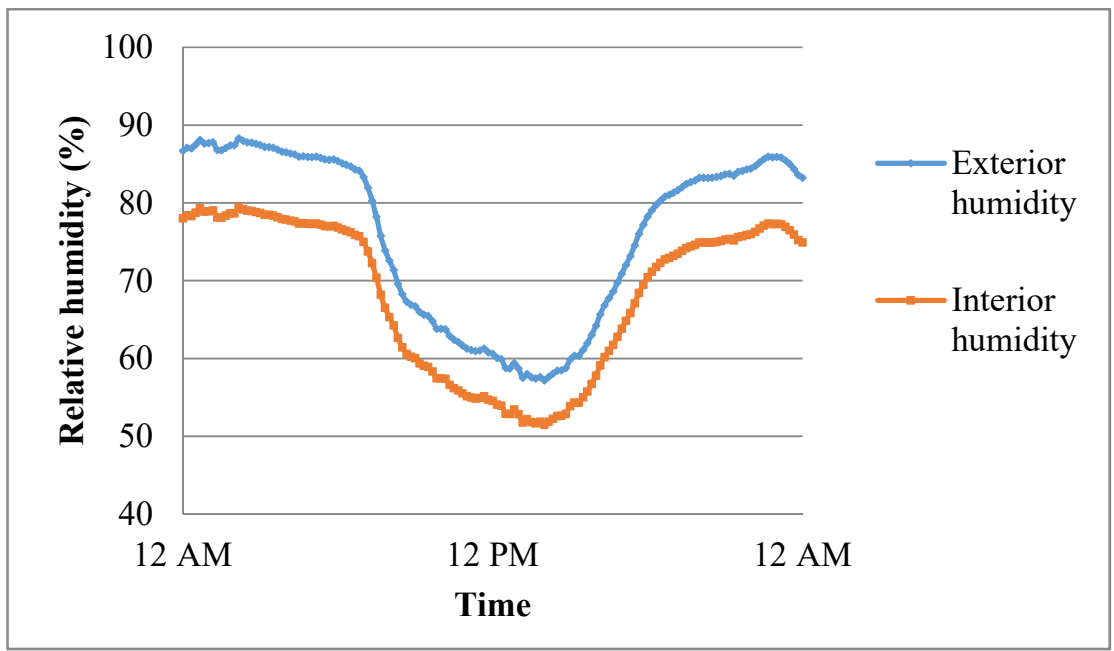

Figure 16. Dependencies for relative interior and exterior humidity during the model day in October.

All external and internal parameters were put into the context of THI. In the conditions of Central Europe, the highest THI values are reached in the summer, when the significant effect of temperature was confirmed, as the humidity had the minimum values. For this reason, the dependencies for the hottest month of the year (July) are presented in Figure 17. The influence of PV modules installation on the THI is summarized in Figure 18.

The results of correlation analysis declared the very high correlation with a coefficient near 1 in both cases. Dependencies were created for extreme values that may occur. The green curve represents the values of THI for maximum temperature and maximum relative humidity, the blue curve represents the THI for maximum temperature and minimum relative humidity. The average difference between values of THI was 2.88 . The calculated value of the THI difference could mean that the comfort limit was exceeded. The opposite extreme represents the dependence of the $\mathrm{THI}$ for the minimum temperature and maximum relative humidity (red curve), as well as the dependence for the minimum values of temperature and humidity (orange curve). The average difference in THI values in this case was 0.05 . 


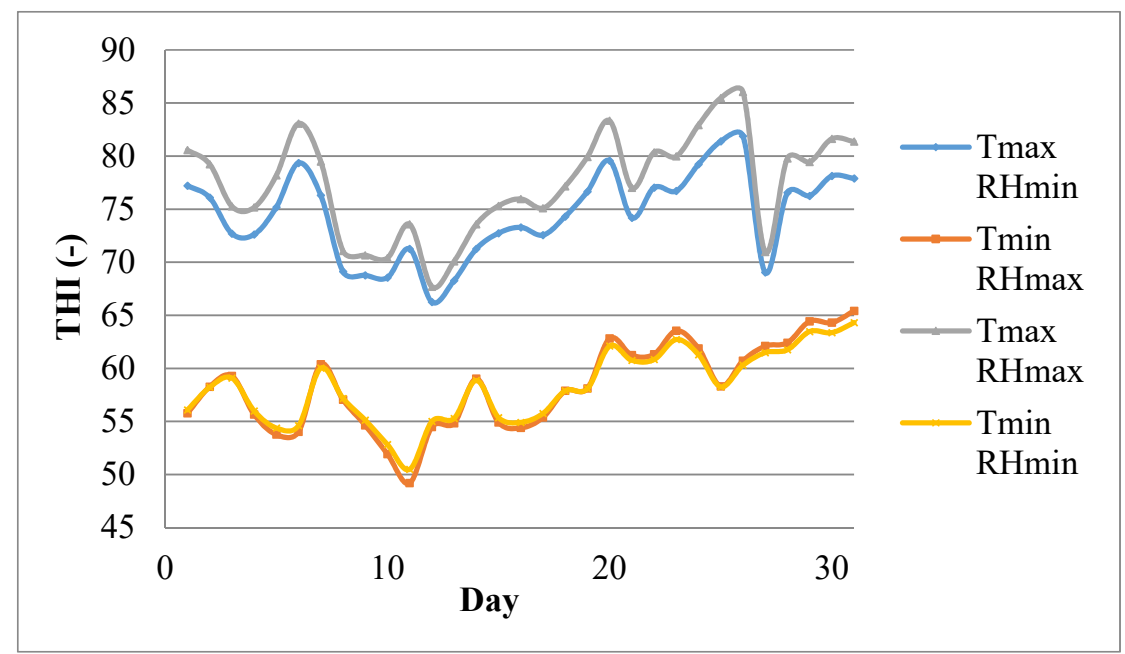

Figure 17. The dependencies for limit values of temperatures and relative humidity and its impact on the THI in July.

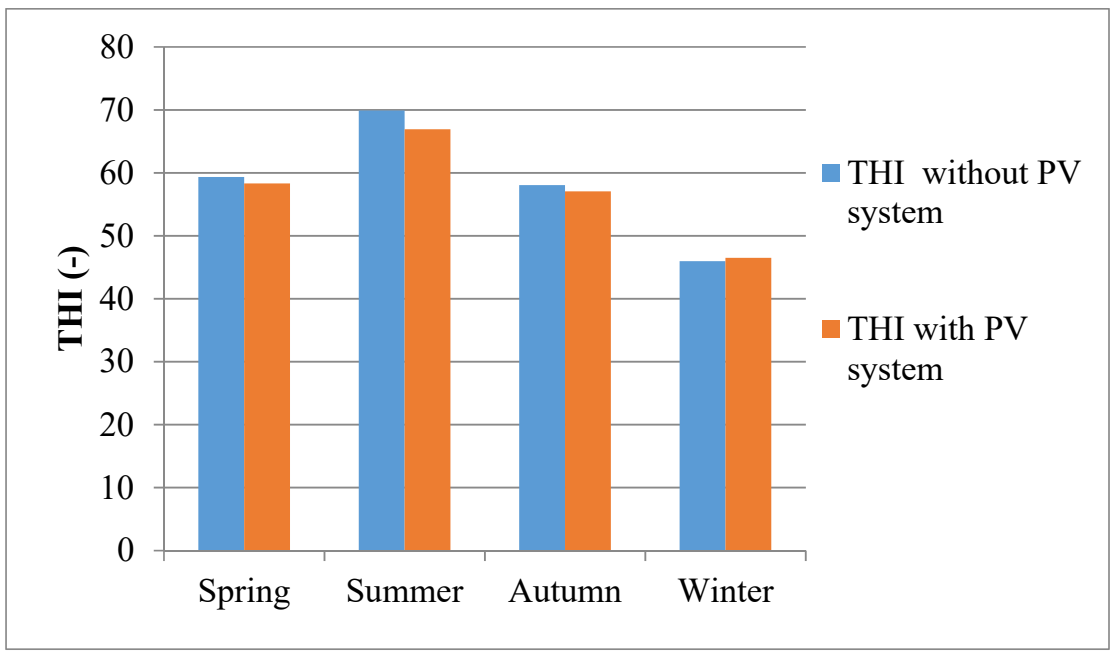

Figure 18. The influence of PV modules installation on the THI values during the year.

Statistical ANOVA test was used to determine the effect of PV on THI (software STATISTICA 10, StatSoft CR Ltd.). F-test in the ANOVA table tests whether there are any significant differences amongst the means. If there are, the Multiple Range Tests tell us which means are significantly different from which others. The F-ratio, which in this case equaled 0.0305954 , was a ratio of the between-group estimate to the within-group estimate. The effect of the THI without PV modules installation on THI with PV installation was caused mainly by the effects within groups THI without PV modules or THI with PV modules because the sum of squares 498.196 was greater than 2.440. That means the variance in the groups was not caused by the interaction between groups. Since the $p$-value 0.8669 of the F-test was greater than 0.05 , there is not a statistically significant difference between the averages of the 2 variables at the $95 \%$ confidence level. The method currently being used to discriminate among the averages was Fisher's least significant difference (LSD) procedure. The results of variation analysis could be influenced by small number of values in Table 3, and also by small changes of parameters. In this case, it is better to apply variance analysis on the day data or for the selected time range during the solar radiation intensity culmination. From the statistical results, it seems that installation of PV modules has not influenced the THI. The external and internal conditions vary during the day. Very important statistical results were obtained for days with extreme temperatures, which are reached during the summer season. For these days a $p$-value of F-test near 
$p=0.0446$ was obtained, which is statistically significant. The same F-test was applied on the data experimentally detected for the winter season, and there were calculated $p$-values near 0.0513 during the days with extreme external conditions. From the comprehensive assessment point of view, even small changes in internal conditions can cause only a slight difference in the THI value. However, during the year, there are many days when small differences in conditions decide whether the THI limit value is exceeded. In terms of ensuring comfortable conditions for breeding, the impact of PV installation in practice is evident.

\section{Discussion}

The similar experiments were performed and summarized by authors [42], but the benefits of our research are results specified for the Central European region, which have not been published yet. They measured the effect of the photovoltaic system installation on the roof to the temperature in the Powell Structural Laboratory in San Diego, California. They used a similar experimental set up as in our research. The temperature differences were also detected by thermal IR camera Fluke TiR1 (Fluke, Washington USA). After the comparison between our results and values in ref. [42] is clear, that ceiling under the roof without photovoltaic module had higher temperature. Ref. [42] presents the time temperature dependencies of ceiling temperatures under the exposed roof and a flat, tilted photovoltaic array.

The difference between exposed roof and flat photovoltaic array is in the temperature peak approximately $2{ }^{\circ} \mathrm{C}$. Results from temperature measurement declared the temperature difference during the temperature culmination was $7.7^{\circ} \mathrm{C}$. The higher value of temperature difference can be caused by the different roof construction. The model roof had no roof insulation (the authors of [42] had a $200 \mathrm{~mm}$ layer of concrete).

The authors of [43] performed similar measurements, and they measured indoor temperature under the fiber-cement roof and photovoltaic roof. They obtained approximately the same values in the time range from 8 a.m. to 12 p.m. From the results, it is evident that that the difference between the temperatures inside was between $1.1^{\circ} \mathrm{C}-1.2{ }^{\circ} \mathrm{C}$.

Our experiment confirmed the same results, that the temperature inside is higher under the roof without installed photovoltaic modules (Figure 19). Average indoor temperature with roof without photovoltaic module was $23.9^{\circ} \mathrm{C}$. For comparison, we selected the day with a polycrystalline module on the roof. It was for this reason that this day had a closer average ambient temperature. Average indoor temperature with roof with photovoltaic module was $22.8^{\circ} \mathrm{C}$. The difference between these two values was $1.1^{\circ} \mathrm{C}$, the same value of temperature difference was presented by authors [43].

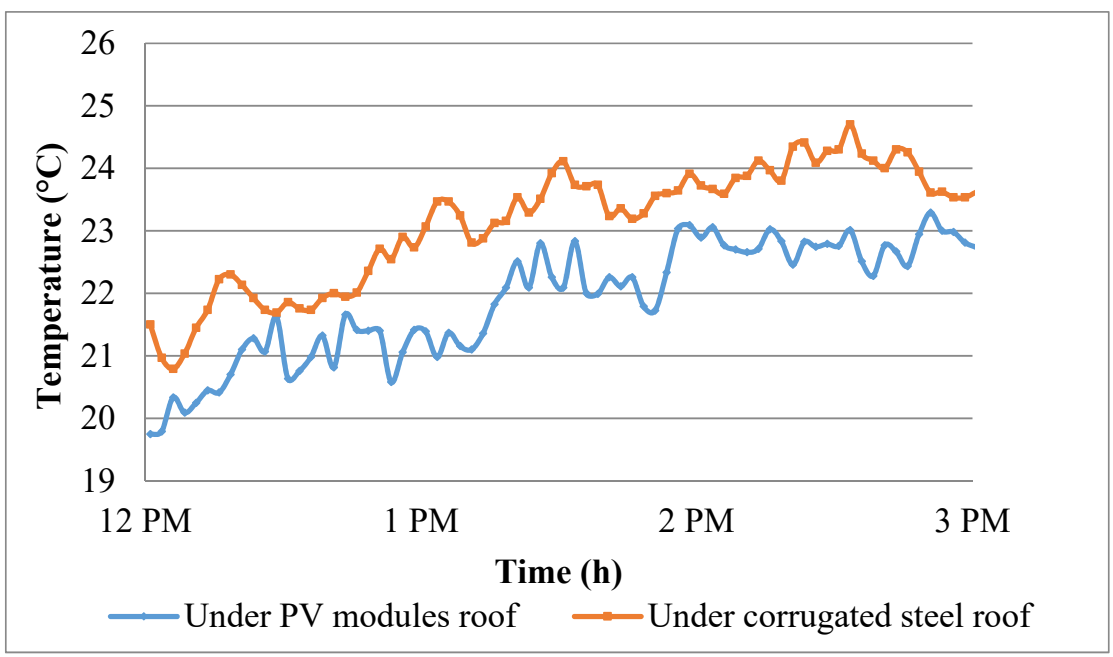

Figure 19. The comparison of temperatures under the roof and under photovoltaic module. 
The heat stress problem is acutely felt in the Central European countries. The weather of these countries is characterized by moderate to high summer temperatures coupled with moderate humidity levels $[44,45]$. Hot weather causes heat stress in dairy cows, leading to declines in milk production each summer. These declines can be reduced or eliminated by using open barns for optimum milk production [46]. The heat stress problem is getting worse as production levels continue to rise $[47,48]$. The basic condition of management in dairy farms consists in understanding what factors affect milk production the most, i.e., with the exception of nutrition and dairy cow health status, also the parity and season of calving, technological systems, and especially microclimatic conditions [49]. Livestock performance is affected by heat stress because an animal having difficulty in losing heat will decrease its heat production by lowering feed intake [32,50]. The upper critical air temperature for lactating cows is in the range of 24 to $27^{\circ} \mathrm{C}$ [23]. However, critical temperatures will vary depending on several factors including degree of acclimatization, rate of production, pregnancy status, air movement around the animals, and relative humidity $[18,51]$. The effect of using the cooling system on thermal comfort was studied by Lendelová et al. (2012) [52].

The facts presented above are in good agreement with the summary of experimental results obtained in the real cowshed. There were calculated values of the TemperatureHumidity-Index (THI) for the real cowshed without PV modules installed on the roof, and also with PV modules placed on the roof. Calculated numerical results created the platform for discussion about the effect of microclimate changes in the animal production building on the animal heat stress.

From the presented experimental results, it is evident that the installation of a PV system on the cowshed decreases the indoor temperature on average by $1.2^{\circ} \mathrm{C}$. The average ambient temperature during the measurements was $23.6^{\circ} \mathrm{C}$. For identification of the PV system installation effect on the THI, the interior temperature for ambient temperature in the range (20-40) ${ }^{\circ} \mathrm{C}$ (see Figure 20) was calculated. Then the THI was calculated by Equation (1). The calculation was done for humidity value $65 \%$. Results are presented in Figure 16. From the mentioned figure, it is clear that the PV system installation has a positive impact on the THI. In the graph are three important points. At ambient temperature $25^{\circ} \mathrm{C}$, which is THI for the cowshed without an installed PV system 73.29, it represents mild stress. The THI for the cowshed with an installed PV system is 71.4, and it represents no stress. At ambient temperature $29^{\circ} \mathrm{C}$, which was cowshed without PV system THI 79.09, which means severe stress. If the ambient temperature in the cowshed with an installed PV system was $29^{\circ} \mathrm{C}$, the THI had value 76.9 , which represents mild stress for animals. The THI 89.24 was found for the cowshed without an installed PV system at ambient temperature $36{ }^{\circ} \mathrm{C}$. This value of the THI represents very severe stress for animals. This condition was identified for the cowshed with an installed PV system at the ambient temperature $38^{\circ} \mathrm{C}$.

At the end of the discussion, we can state that all presented results are also in agreement with thermal theory, where the $U$ thermal transmittance coefficient is defined as the measurement unit for determining the loss of heat in a building element. It expresses the quantity of heat which crosses a square meter of a building element per second for a temperature difference of $1{ }^{\circ} \mathrm{C}$ between internal and external air. The lower $U$ value represents the higher thermal insulation. For example, the polycrystalline photovoltaic module with insulated glazing has, according to the standard EN 673 (Glass in building-Determination of thermal transmittance $\mathrm{U}$ value-Calculation method), the $\mathrm{U}$ value $1.1 \mathrm{~W} \cdot \mathrm{m}^{-2} \cdot \mathrm{K}^{-1}$ [53]. The same $U$ value applies to a double insulated glazing window with argon filling [54] and approximately the same $\mathrm{U}$ value also applies to the PV module. The commercial PV modules have the $\mathrm{U}$ value from range $(0.8-2.5) \mathrm{W} \cdot \mathrm{m}^{-2} \cdot \mathrm{K}^{-1}$, in our experiments we used $\mathrm{PV}$ modules with a $\mathrm{U}$ value ca. $1.5 \mathrm{~W} \cdot \mathrm{m}^{-2} \cdot \mathrm{K}^{-1}$.

The next problem which can be discussed is the type of installation. There were performed measurements in the frame of bilateral cooperation between SUA in Nitra and Mendel University in Brno. The research was focused on the comparison of PV system 
energy for two ways of the PV modules installation. At first, the PV modules were installed on the roof, and the same PV system was installed on the wall of the same building. The research results showed fact that better results were obtained for the PV modules placed on the facade of the building, but only in the winter season. In other seasons, the vertical installation had a negative effect on the PV system energy balance. This result was found only for the conditions of Central Europe. The comprehensive summary of study results has not been published yet.

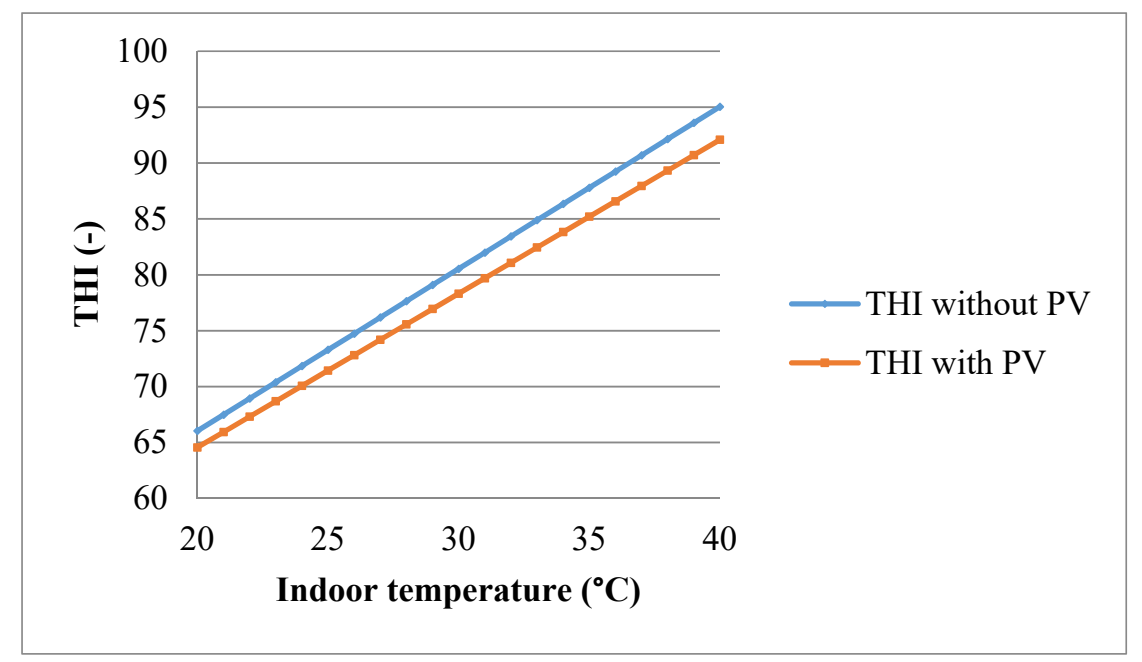

Figure 20. Relations between the THI and the indoor temperature for cowshed with and without installed PV system on the roof.

\section{Conclusions}

The installation of a PV system on the roof of animal production building had some benefits from the practice point of view. The first benefit is well known, it is positive energetic balance, because the PV system can produce the electricity for consumption, ventilation, and heating. The second benefit is the improvement of the microclimate in the cowsheds. This fact was confirmed experimentally for the model and real cowshed, because after the PV module's installation, the interior temperature of the cowshed in the cold seasons (winter, late autumn, early spring) increased, because the PV modules form a thermal insulation layer, which helps to some extent increase the temperature inside. During the hot seasons (summer, late spring, and early autumn) the situation was opposite; the installation of the PV modules reduces the internal temperature in the cowshed, thereby reducing the thermal stress of the animals. The results of the performed experiments on the model building and real building confirmed that the installation of the PV system on the roof of cowshed has a positive influence on the internal temperature, and thus on the animal heat stress during the year. All presented results were evaluated in the context of the internal and external conditions. There were detected correlations between the intensity of solar radiation and ambient temperature as well as interior temperature. Because heat transport can be separated from the moisture transport, the changes of interior temperatures are in connection with humidity changes, and these factors are unified by the THI, which was calculated and discussed, because it can characterize the animal stress, which is influenced by changes of microclimate conditions. The presented results declared a strong impact of the temperatures and the partial influence of the air relative humidity and its velocity on the THI. The results mentioned before are very valuable for practice because they provide a platform for optimizing internal conditions in cowsheds by monitoring internal and external breeding parameters. The results also confirm the positive effect of installing PV to achieve a slight improvement in THI values. This fact is important mainly during the seasonal temperature extremes in summer in the Central European region. From 
the practice point of view, heat stress has become a major concern for dairy producers because of the associated decreases in milk production and large economic losses.

Author Contributions: Conceptualization, M.B. (Matúšs Bilč́ik) and M.B. (Monika Božiková); methodology, M.B. (Matúš Bilčík) and M.B. (Monika Božiková); software, M.B. (Matúš Bilčík); validation, M.B. (Matúš Bilčík) and J.Č., formal analysis M.B. (Matúš Bilčík), M.B. (Monika Božiková) and J.Č.; investigation, M.B. (Matúš Bilčík), M.B. (Monika Božiková) and J.Č.; resources, M.B. (Matúš Bilčík) and J.Č.; writing—original draft preparation, M.B. (Matúš Bilčík) and M.B. (Monika Božiková); writing—review and editing, M.B. (Matúš Bilčík) and M.B. (Monika Božiková); visualization, M.B. (Matúš Bilč́́k); supervision, M.B. (Monika Božiková); project administration, J.Č.; funding acquisition, J.Č. All authors have read and agreed to the published version of the manuscript.

Funding: This publication was funded by the Cultural and Educational Grant Agency KEGA Project No 026SPU-4/2020 and by the Operational Program Integrated Infrastructure within the project: Demand-driven research for the sustainable and innovative food, Drive4SIFood 313011V336, cofinanced by the European Regional Development Fund.

Institutional Review Board Statement: Not applicable.

Informed Consent Statement: Not applicable.

Data Availability Statement: The data presented in this study are available in the main text of this document.

Conflicts of Interest: The authors declare no conflict of interest.

\section{References}

1. Poulek, V.; Dang, M.Q.; Libra, M.; Beránek, V.; Šafránková, J. PV Panel with Integrated Lithium Accumulators for BAPV Applications-One Year Thermal Evaluation. IEEE J. Photovolt. 2020, 10, 150-152. [CrossRef]

2. Christensen, J.; Hewitson, B.; Busuioc, A.; Chen, A.; Gao, X.; Held, I.; Jones, R.; Kolli, R.; Kwon, W.T.; Laprise, R.; et al. Regional Climate Projections. In IPCC Climate Change 2007: The Physical Science Basis; Solomon, S., Qin, D., Manning, M., Hen, Z., Marquis, M., Averyt, K., Tignor, M., Miller, H., Eds.; Cambridge University Press: Cambridge, UK; New York, NY, USA, 2007.

3. Van Oldenborgh, G.; Collins, M.; Arblaster, J.; Christensen, J.H.; Marotzke, J.; Power, S.; Rummukainen, M.; Zhou, T. Annex I: Atlas of Global and Regional Climate Projections. In Climate Change 2013: The Physical Science Basis; Stocker, T., Qin, D., Plattner, G.-K., Tignor, M., Allen, S., Boschung, J., Nauels, A., Xia, Y., Bex, V., Midgley, P., Eds.; Cambridge University Press: Cambridge, UK; New York, NY, USA, 2013.

4. Kjellström, E.; Nikulin, G.; Strandberg, G.; Christensen, O.B.; Jacob, D.; Keuler, K.; Lenderink, G.; van Meijgaard, E.; Schär, C.; Somot, S. European climate change at global mean temperature increases of 1.5 and $2{ }^{\circ} \mathrm{C}$ above pre-industrial conditions as simulated by the 30 EURO-CORDEX regional climate models. Earth Syst. Dyn. 2018, 9, 459-478. [CrossRef]

5. Nardone, A.; Ronchi, B.; Lacetera, N.; Ranieri, M.S.; Bernabucci, U. Effects of climate changes on animal production and sustainability of livestock systems. Livest. Sci. 2010, 130, 57-69. [CrossRef]

6. Hempel, S.; Menz, C.; Pinto, S.; Galán, E.; Janke, D.; Estellés, F.; Müschner-Siemens, T.; Wang, X.; Heinicke, J.; Zhang, G.; et al. Heat stress risk in European dairy cattle husbandry under different climate change scenarios-Uncertainties and potential impacts. Earth Syst. Dyn. Discuss. 2019, 10, 859-884. [CrossRef]

7. Armstrong, D.V. Heat stress interaction with shade and cooling. J. Dairy Sci. 1994, 77, 2044-2050. [CrossRef]

8. Klinedinst, P.L.; Wilhite, D.A.; Hahn, G.L.; Hubbard, K.G. The potential effects of climate change on summer season dairy cattle milk production and reproduction. Clim. Chang. 1993, 23, 21-36. [CrossRef]

9. Rhoads, M.; Rhoads, R.; VanBaale, M.; Collier, R.; Sanders, S.; Weber, W.; Crooker, B.; Baumgard, L. Effects of heat stress and plane of nutrition on lactating Holstein cows: I. Production, metabolism, and aspects of circulating somatotropin. J. Dairy Sci. 2009, 92, 1986-1997. [CrossRef] [PubMed]

10. Silanikove, N.; Shapiro, F.; Shinder, D. Acute heat stress brings down milk secretion in dairy cows by up-regulating the activity of the milk-borne negative feedback regulatory system. BMC Physiol. 2009, 9, 13. [CrossRef] [PubMed]

11. Dikmen, S.; Hansen, P.J. Is the temperature-humidity index the best indicator of heat stress in lactating dairy cows in a subtropical environment? J. Dairy Sci. 2009, 92, 109-116. [CrossRef]

12. Allen, J.D.; Hall, L.W.; Collier, R.J.; Smith, J.F. Effect of core body temperature, time of day, and climate conditions on behavioral patterns of lactating dairy cows experiencing mild to moderate heat stress. J. Dairy Sci. 2015, 98, 118-127. [CrossRef]

13. Hu, H.; Zhang, Y.; Zheng, N.; Cheng, J.; Wang, J. The effect of heat stress on gene expression and synthesis of heat-shock and milk proteins in bovine mammary epithelial cells. Anim. Sci. J. 2016, 87, 84-91. [CrossRef]

14. Renaudeau, D.A.; Collin, S.; Yahav, V.; De Basilio, J.L.; Gourdine, R.J. Adaptation to hot climate and strategies to alleviate heat stress in livestock production. Animal 2012, 6, 707-728. [CrossRef] [PubMed]

15. West, J.W. Effects of heat stress on production in dairy cattle. J. Dairy Sci. 2003, 86, 2131-2144. [CrossRef] 
16. Kadzere, C.T.; Murphy, M.R.; Silanikove, N.; Maltz, E. Heat stress in lactating dairy cows: A review. Livest. Prod. Sci. 2002, 77, 59-91. [CrossRef]

17. Bohmanova, J.; Misztal, I.; Cole, J.B. Temperature-Humidity Indices as Indicators of Milk Production Losses due to Heat Stress. J. Dairy Sci. 2007, 90, 1947-1956. [CrossRef]

18. Mader, T.L.; Davis, M.S. Effect of management Effect of management strategies on reducing heat stress of feedlot cattle: Feed and water intake. J. Anim. Sci. 2004, 82, 3077-3087. [CrossRef]

19. Noordhuizen, J.; Bonnefoy, J.M. Heat Stress in Dairy Cattle: Major Effects and Practical Management Measures for Prevention and Control. Symbiosis J. Vet. 2015, 1, 103-109. [CrossRef]

20. Ravagnolo, O.; Misztal, I. Genetic component of heat stress in dairy cattle, parameter estimation. J. Dairy Sci. 2000, 83, 2126-2130 [CrossRef]

21. Steadman, R.G. The assessment of sultriness, part 1: A temperature-humidity index based on human physiology and clothing science. J. Appl. Meteorol. 1979, 18, 861-873. [CrossRef]

22. Huber, J.T.; Higginbotham, G.; Gomez-Alarcon, R.A.; Taylor, R.B.; Chen, K.H.; Chan, S.C.; Wu, Z. Heat stress interactions with protein, supplemental fat and fungal cultures. J. Dairy Sci. 1994, 77, 2080-2090. [CrossRef]

23. Igono, M.O.; Bjovedt, G.; Sanford-Crane, H.T. Environmental profile and critical temperature effects on milk production of Holstein cows in desert climate. Intern. J. Biometeorol. 1992, 36, 77-87. [CrossRef] [PubMed]

24. Johnson, H.D.; Ragsdale, A.C.; Berry, I.L.; Shanklin, M.D. Temperature-Humidity effects including influence of acclimation in feed and water consumption of Holstein cattle. Res. Bull. 1963, 846, 68-76.

25. Nienaber, J.A.; Hahn, G.L.; Eigenberg, R.A. Quantifying livestock responses for heat stress management: A review. Int. J. Biometeorol. 1999, 42, 183-188. [CrossRef]

26. Stevenson, J. To make pregnancies, cool those cows. Hoard's Dairym. Juillet 2007, 2007, 500.

27. Brouček, J.; Novák, P.; Vokřálová, J.; Šoch, M.; Kišac, P.; Uhrinčat', M. Effect of high temperature on milk production of cows from freestall housing with natural ventilation. Slovak J. Anim. Sci. 2009, 42, 167-173.

28. Herbut, P.; Angrecka, S.; Walczak, J. Environmental parameters to assessing of heat stress in dairy cattle-A review. Int. J. Biometeorol. 2018, 62, 2089-2097. [CrossRef]

29. Buffington, D.E.; Collazo-Arocho, A.; Canton, G.H.; Pitt, D.; Thatcher, W.W.; Collier, R.J. Black globe-humidity index (BGHI) as comfort equation for dairy cows. Trans. ASAE 1981, 24, 711-714. [CrossRef]

30. Da Silva, R.G.; Guilhermino, M.M.; Morais, D.A.E.F. Thermal radiation absorbed by dairy cows in pasture. Int. J. Biometeorol. 2009, 54, 5-11. [CrossRef]

31. Shioya, S.; Terada, F.; Iwama, Y. Physiological responses of lactating dairy cows under hot environments. Eiyoseirikenkyukaiho 1997, 41, 61-68.

32. Davis, S.; Mader, T.L. Adjustments for Wind Speed and Solar Radiation to the Temperature-Humidity Index. Nebr. Beef Cattle Rep. 2003, 224, 49-51.

33. Heinicke, J.; Hoffmann, G.; Ammon, C.; Amon, B.; Amon, T. Effects of the daily heat load duration exceeding determined heat load thresholds on activity traits of lactating dairy cows. J. Therm. Biol. 2018, 77, 67-74. [CrossRef]

34. Amaducci, S.; Yin, X.; Colauzzi, M. Agrivoltaic systems to optimise land use for electric energy production. Appl. Energy 2018, 220, 545-561. [CrossRef]

35. Majumdar, D.; Pasqualetti, M.J. Dual use of agricultural land: Introducing 'agrivoltaics' in phoenix metropolitan statistical area, usa. Landsc. Urban Plan. 2018, 170, 150-168. [CrossRef]

36. Dinesh, H.; Pearce, J.M. The potential of agrivoltaic systems. Renew. Sustain. Energy Rev. 2016, 54, 299-308. [CrossRef]

37. Parkinson, S.; Hunt, J. Economic potential for rainfed agrivoltaics in groundwater-stressed regions. Environ. Sci. Technol. Lett. 2020, 7, 525-531. [CrossRef]

38. Valle, B.; Simonneau, T.; Sourd, F.; Pechier, P.; Hamard, P.; Frisson, T.; Ryckewaert, M.; Christophe, A. Increasing the total productivity of a land by combining mobile photovoltaic panels and food crops. Appl. Energy 2017, 206, 1495-1507. [CrossRef]

39. SZ-50-36M. Available online: http://www.solarfam.nl/_voltronicpower/download/solarfam-rigid-solar-panels.pdf (accessed on 28 September 2020).

40. SPP50-10/3a. Available online: https://www.mulac.cz/userfiles/file/Datasheet-BlueSolarPolycrystallinePanels-09.pdf (accessed on 28 September 2020).

41. REED TP-01 Type K Beaded Wire Probe. Available online: http://www.reedinstruments.com/product/reed-tp-01-type-kthermocouple (accessed on 28 September 2020).

42. Dominguez, A.; Kleissl, J.; Luvall, J. Effects of solar photovoltaic panels on roof heat transfer. Sol. Energy 2011, 85, 2244-2255. [CrossRef]

43. Bonifacius, N.; Ekasiwi, S. Small Scale Experiment: Thermal Performance Comparison Between Fiber-Cement Roof and Photovoltaic Roof In Malang, Indonesia. Makara. J. Technol. Ser. 2013, 16, 99-102. [CrossRef]

44. Beatty, D.T.; Barnes, A.; Taylor, E.; Pethick, D.; McCarthy, M.; Maloney, S.K. Physiological responses of Bos taurus and Bos indicus cattle to prolonged, continuous heat and humidity. J. Anim. Sci. 2006, 84, 972-985. [CrossRef] [PubMed]

45. Brouček, J.; Mihina, Š.; Ryba, Š.; Tongel', P.; Kršac, P.; Unrinčat', M.; Hanus, A. Effects of high air temperatures on milk efficiency in dairy cows. Czech J. Anim. Sci. 2006, 51, 93-101. [CrossRef] 
46. Mihina, Š.; Kažimírova, V.; Copland, T.A. Technology for Farm Animal Husbandry, 1st ed.; Slovak Agricultural University: Nitra, Slovakia, 2012.

47. Brouček, J.; Ryba, Š.; Mihina, Š.; Uhrinčat', M.; Kišac, P. Impact of thermal-humidity index on milk yield under conditions of different dairy management. J. Anim. Feed Sci. 2007, 16, 329-344. [CrossRef]

48. Segnalini, M.; Bernabucci, U.; Vitali, A.; Nardone, A.; Lacetera, N. Temperature humidity index scenarios in the Mediterranean basin. Int. J. Biometeorol. 2013, 57, 451-458. [CrossRef] [PubMed]

49. Maust, L.E.; Mcdowell, R.E.; Hooven, N.W. Effects of summer weather on performance of Holstein cows in three stages of lactation. J. Dairy. Sci. 1972, 55, 1133-1139. [CrossRef]

50. Mader, T.L.; Davis, M.S.; Brown-Brandl, T. Environmental factors influencing heat stress in feedlot cattle. J. Dairy Sci. 2006, 84, 712-719. [CrossRef]

51. Aharoni, Y.; Brosh, A.; Ezra, E. Effects of heat load and photoperiod on milk yield and composition in three dairy herds in Israel. Anim. Sci. 1999, 69, 37-47. [CrossRef]

52. Lendelova, J.; Botto, L.; Pogran, Š.; Szabóova, T. Effect of different cooling systems on lying time of dairy cows in cubicles with separated manure solids bedding. J. Cent. Eur. Agric. 2012, 13, 717-728. [CrossRef]

53. Heat Transfer Coefficient. Available online: http://www.bipv.ch/index.php/en/technology-top-en/thermal-aspects/heattransfer-coefficient (accessed on 2 October 2020).

54. U Value for Windows. Available online: https://www.deceuninck.de/en-gb/u-value-for-windows/\# (accessed on 2 October 2020). 